\title{
Novas imagens da pombagira na cultura pop: símbolos, mitos e estereótipos em circulação ${ }^{1}$ New images of pombagira in pop culture: symbols, mythos and stereotypes in circulation
}

Florence Marie Dravet ${ }^{2}$

Leandro Bessa Oliveira ${ }^{3}$

Resumo Como o arquétipo da mulher selvagem sobrevive e ressurge dentro de construções estereotipadas do feminino na cultura pop contemporânea, especialmente na música e nos videoclipes? Para tratar desse arquétipo, partimos da figura brasileira da pombagira, símbolo de uma força feminina livre, selvagem, sensual e sexual. De acordo com a teoria de Warburg (2012), símbolos fortes ressurgem na arte devido ao caráter recorrente do pathos, que ele denomina Pathosformel. Mostraremos, com o estudo de três figuras do feminino no star system mediático, como um feminino livre, embora tenha sido devastado por séculos de falocentrismo, está ressurgindo e se manifestando na cultura pop.

Palavras-chave: Cultura pop; Pombagira; Valesca Popozuda; Lady Gaga; Azis

\footnotetext{
Abstract How the archetype of the Wild Woman survives and resurfaces within stereotypical constructions of the feminine in contemporary pop culture, especially in music and video clips? To address this archetype, we start from the Brazilian figure pombagira, symbol of a free, wild, sensual and sexual female strength. According to the theory of Warburg (2012), strong symbols reappear in the art due to the recurring nature of pathos, which he calls Pathosformel. We will

${ }^{1}$ Este artigo é fruto do projeto de pesquisa "O feminino da tradição afro-brasileira à cultura brasileira- estudo da figura da pombagira, suas imagens e imaginários mediáticos", apoiado pelo edital MCTI/CNPq/MEC/Capes n ${ }^{\circ}$ 43/2013.

2 Universidade Católica de Brasília - UCB, Brasília, DF, Brasil.

E-mail: flormd@gmail.com

${ }^{3}$ Universidade Católica de Brasília - UCB, Brasília, DF, Brasil.

E-mail: lbessa.arte@gmail.com
} 
50 NOVAS IMAGENS DA POMBAGIRA NA CULTURA POP

show, with the study of three female figures of the star system media how a free female, although it has been ravaged by centuries of phallocentrism, is resurfacing and manifesting in pop culture.

Keywords: Pop culture; Pombagira; Valesca Popozuda; Lady Gaga; Azis 
Partindo do princípio da comunicação como modo de circulação da cultura (MORIN, 2007), o presente artigo pretende mostrar como o arquétipo da mulher selvagem sobrevive e ressurge dentro de construções estereotipadas da mulher e do feminino na cultura pop contemporânea. Partimos da figura brasileira da pombagira, símbolo de uma força feminina livre, selvagem, sensual e sexual anterior à dominação masculina da cultura falocêntrica e baseado em um tipo de racionalidade do sensível: a do "regime noturno" (DURAND, 2012), a racionalidade nascida de um feminino presente no corpo da mulher, cujo vazio vaginal não constitui uma falta, mas sua própria força. A força daquela que contém, recebe, compreende; força continente, plena de um vazio que, longe de ser passivo, constitui uma potencialidade criadora.

O arquétipo (JUNG, 2011) - imagem primordial amorfa existente no imaginário - é força e potência para a ação criativa do homem, uma imagem do nebuloso inconsciente coletivo que toma forma na arte e na religião. Já a noção de Pathosformel (WARBURG, 2012) permite entender como os símbolos presentes nas imagens se perpetuam através das culturas, tomando formas diferentes, originárias das mesmas paixões. Sendo assim, não basta identificar o arquétipo, é necessário encontrar o lugar do pathos que atualiza o arquétipo na arte e o faz se perpetuar, tomando formas diversas em culturas as mais diferentes. Seguiremos o percurso do arquétipo ao símbolo na umbanda brasileira pela forma como a força feminina primordial é simbolizada pelo Igbadu e, passando pelas deusas Iemanjá e Oxum, acaba por se manifestar na pombagira. Esse percurso norteará nossa leitura interpretativa da presença de um feminino mediático estereotipado pela cultura pop, cujo discurso circulante nos parece chamar de volta o arquétipo africano do feminino selvagem: livre, sensual e sexual. Como Warburg, em seu Atlas Mnémosyne (2012), aproximamos imagens aparentemente dispersas em culturas diversas.

Sabemos que o arquétipo é amorfo e toma forma através das narrativas míticas, tornando-se, então, imagem simbólica. Sendo determinadas

\footnotetext{
4 Sobre aproximações e distinções entre arquétipo, para Jung, e Pathosformel, para Warburg, ver SCARSO, Davide. Fórmulas e arquétipos, Aby Warburg e Carl Gustav Jung. Enciclopédia e hipertexto. Disponível em: http:/www.educ.fc.ul.pt/hyper/resources/dscarso/. Acesso em: 23 jun. 2014.
} 
pela cultura, tais imagens são objeto de inúmeras variações. Sustentamos aqui que a representação mediática, com o excesso e a velocidade das imagens geradas pelo sistema “iconofágico” (BAITELLO JR., 2005), acaba produzindo estereótipos, formas de degradação dos símbolos e de esvaziamento do sentido das imagens. Todavia, a circularidade do processo de significação na cultura se completa quando a força arquetípica que originou os estereótipos é reencontrada e reformulada. É o que sustenta Durand, quando afirma:

A representação não pode, sob pena de alienação, permanecer constantemente com as armas prontas em estado de vigilância. O próprio Platão sabe que é necessário descer de novo à caverna, tomar em consideração o ato de nossa condição mortal e fazer, tanto quanto pudermos, bom uso do tempo. Do mesmo modo, o psicoterapeuta recomenda, na prática ascensional do sonho acordado, não largar o sonhador no cimo de sua ascensão, mas fazê-lo voltar progressivamente ao seu nível de partida, trazê-lo suavemente à sua altitude mental habitual (DURAND, 2012, p. 193).

Trataremos de alguns desses estereótipos e veremos como, dentro de um universo mediático de símbolos "degradados" pelo excesso de luz, ressurgem símbolos fortes, como ressurgências noturnas. De acordo com a teoria warburguiana, ${ }^{5}$ esses símbolos fortes reaparecem devido ao caráter atávico do pathos, que ele denomina Pathosformel. ${ }^{6}$ É isso que mostraremos com o estudo de três figuras do feminino no star system

\footnotetext{
${ }^{5}$ Aby Warburg realizou procedimentos comparativos de imagens sem se preocupar com delimitações geográficas e cronológicas. Seu modelo de análise se dava através dos vestígios não lineares e não representativos/simbólicos da imagem, um modelo que se exprime na "obsessão" e nas "sobrevivências", nas reminiscências e reaparições das formas, ou seja, "por não-saberes, por irreflexões, por inconscientes do tempo", conforme definiu Georges Didi-Huberman (2013, p. 25). Para Charbel (2010), seu método de trabalho se opunha à análise puramente formal: ele se recusava a abordar as imagens a partir de uma hermenêutica caracterizada pela interpretação dos registros pictóricos do passado a partir de chaves encontradas exclusivamente nas pinturas e/ou na subjetividade do analista.

${ }^{6}$ Segundo Roland Recht, no ensaio de abertura do Atlas Mnémosyne (2012), o termo Pathosformel foi empregado pela primeira vez em 1905, em uma conferência sobre Albrecht Dürer - Dürer e a Antiguidade italiana -, para designar um padrão figurativo que o Renascimento retomou da Antiguidade, bem como forma superlativa de expressão das paixões. Para Didi-Huberman (2013), o Pathosformel seria um traço significante, um traçado em ato das imagens antropomórficas do Ocidente antigo e moderno: algo pelo qual e por onde a imagem pulsa, move-se, debate-se na polaridade das coisas.
} 
mediático: a norte-americana Lady Gaga, a brasileira Valesca Popozuda e o búlgaro Azis. Três estrelas pop. Três símbolos da força da pombagira na cultura contemporânea. Uma retomada do discurso do feminino na sociedade contemporânea localizada em espaços culturais e geográficos distintos. Em busca, portanto, do percurso do arquétipo feminino da mulher selvagem e do Pathosformel que o expressa, acompanharemos primeiramente o trajeto do feminino na cosmologia umbandista e na formação do mito da pombagira. Veremos como a cultura falocêntrica transformou esse mito arquetípico naquele da puta e como a cultura mediática produziu imagens desses símbolos femininos reduzidos a estereótipos de mulheres-objeto. Por fim, analisaremos como Lady Gaga, Valesca Popozuda e Azis fazem ressurgir a potência criadora da mulher selvagem. Identificaremos neles o retorno da pombagira como figura arquetípica e do regime noturno das imagens.

\section{Do arquétipo ao mito afro-brasileiro}

Na simbologia afro-brasileira, as Senhoras dos Pássaros, ou Grandes Mães, são a entidade máxima de representação da força feminina. Elas são representadas por uma grande cabaça formada por duas partes unidas, chamada Igbadu ou "a cabaça do universo" (OXALÁ, 1998; SANTOS, 2001). A metade inferior - o receptáculo - representa o feminino, enquanto a metade superior representa o masculino. O que há dentro não deve ser revelado. Separar as metades seria romper com a ordem do mistério.

Guardado o mistério das Senhoras dos Pássaros na cabaça fechada, os orixás manifestam alguns de seus aspectos nas suas aparições e atuações sobre a Terra junto aos homens e à natureza. Já vimos, em artigo anterior, ${ }^{7}$ como

\footnotetext{
7 Ver o artigo "A formação das imagens do feminino na cosmologia da umbanda e sua manifestação no imaginário brasileiro", apresentado ao grupo de trabalho Imaginário e Imagens Midiáticas do XXII Encontro Anual da Compós, em Salvador, em junho de 2013.
} 
os poderes guardados e simbolizados pelos orixás femininos se sintetizam em poder matricial original (Nanã), poder selvagem e guerreiro (Obá e Iansã), poder de geração (Iemanjá e Oxum), poder de sedução (Oxum e Iansã) e poder mágico (Iewá). [...] Embora possamos determinar o tipo de poder correspondente a cada orixá, é fato também que todos se encontram reunidos em todos os orixás femininos, constituindo, talvez, uma só força feminina do universo, que dá a vida, gera, transforma, ama e cria. (DRAVET, 2013, p. 10)

Iemanjá - talvez a orixá mais popular do Brasil, pela importância do mar no povoamento do país - é a deusa do mar, sincretizada com a Virgem Maria. É também a mãe de todos os peixes ou a mãe espiritual de todos os homens. Oxum, sua filha, igualmente muito popular no Brasil, é a grande geradora. Seu elemento é a água dos rios, representando o líquido amniótico onde os filhos são gerados. Sua força é a do amor. É preciso explicar que os orixás africanos passaram, no Brasil, por um processo de transformação e adaptação às condições culturais locais. Sendo assim, pouco a pouco, foi retirado de Iemanjá e Oxum, pela sua aproximação à Virgem Maria, seu caráter sexual e lascivo, então canalizado para a figura da pombagira.

No Brasil, há pouca literatura sobre as pombagiras; no entanto, uma pesquisa de campo junto a pessoas não adeptas revela que a figura é muito presente no imaginário coletivo. Não há quem nunca tenha ouvido falar nela e quem não saiba alguma coisa a seu respeito. Geralmente, a menção à pombagira suscita reações de espanto nas pessoas, que podem se expressar através do riso e do deboche ou, ao contrário, de respostas monossilábicas ou do silêncio incomodado. O nome é imediatamente associado à imagem de uma prostituta, uma mulher de vida livre, sedutora e perigosa. A rigor, toda mulher tem uma moça (outra denominação das pombagiras), e alguns homens femininos também a têm. Ela é uma espécie de companheira que garante a feminilidade. Enquanto alguns temem a pombagira, chamam-na de perigosa, influente, maldosa, capaz de feitiços e amarrações, outros se sentem fascinados pelo seu poder de sedução, pelo seu conhecimento de feitiçaria que lhe permite obter qualquer coisa em matéria de amor e relacionamentos. 
É necessário salientar que a vivência da pombagira pelos adeptos da umbanda se dá pela incorporação e diz respeito aos aspectos emocionais da vida dos homens e das mulheres do terreiro: seus sentimentos, suas relações amorosas, sua sexualidade, sua expressividade corporal e verbal. Alguns homens não gostam da incorporação da pombagira porque ela os remete a seu lado feminino, que tendem a negar. Já outros relatam amar a oportunidade de exteriorizar seu lado feminino, sorrir, falar, gargalhar e gesticular como mulher. De fato, a pombagira gargalha, canta, xinga, usa vocabulário chulo, às vezes vulgar, quebra todas as barreiras, os tabus, expressa aquilo que não se ousa expressar, dança e gira para tirar o corpo da imobilidade, incita ao movimento e à ação. Nesse sentido, ela pode ser considerada como um tipo dionisíaco do feminino. Gosta de zombar, debochar, rir de tudo aquilo que as civilidades impõem como limitação aos homens e às mulheres. Seu campo preferido de atuação é o dos relacionamentos amorosos e, mais especialmente, o da sexualidade dos homens e das mulheres.

A pombagira atua, portanto, nas regiões da vida social onde residem os maiores tabus: o amor e a sexualidade. Talvez seja possível afirmar que os clichês simplificadores que fazem da pombagira uma figura negativa associada à prostituta, à mulher histérica e à bruxa perigosa são as máscaras sob as quais o feminino ama se ocultar para melhor preservar o seu poder criativo, intuitivo, amoroso. Se ela gosta de rir e de jogar, se faz pouco-caso das civilidades e prefere a liberdade, se ela é movimento e ação, não surpreende que a pombagira jogue e ria com aquilo que mais desestabiliza o homem: sua sexualidade; com aquilo que talvez seja o maior desafio, ao mesmo tempo espiritual e material, do homem: o amor.

Veremos, agora, como nossa cultura, dominada por valores patriarcais, interpretou e transformou a pombagira em algumas imagens estereotipadas de puta, cuja lascívia a transforma em figura maligna. E como algumas figuras femininas da cultura mediática pop contemporânea fazem uso desses estereótipos para criar um discurso sobre o feminino que muito se aproxima da força arquetípica da pombagira. 


\section{Do mito afro-brasileiro às luzes da cultura falocêntrica}

$\mathrm{Na}$ iconografia e nos discursos da cultura judaico-cristã, temos duas matrizes diurnas do feminino, manifestas e opostas. Por um lado, a Virgem Maria, pura, que, no Apocalipse, é a "mulher revestida de sol", a cabeça cindida por uma coroa de 12 estrelas e os pés apoiados sobre a lua. Essa Virgem Maria também toma outras formas e é objeto de diversas versões de santidade, perfeição e bondade. Sobretudo, serve de modelo moralizador para as mulheres destinadas a serem mães, a verem seus instintos sexuais podados pelas noções cristãs de virgindade e santidade, a se dedicarem à educação dos filhos e à boa condução da economia do lar etc. Todos valores cristãos que, ainda hoje, dominam a razão e a moral da sociedade patriarcal.

Nessa mesma iconografia judaico-cristã, temos, por outro lado, a mulher pecadora e causadora de todos os vícios da Babilônia: "a grande prostituta sobre as águas" do Apocalipse bíblico, que, ao longo da história, tem outras denominações e toma outras formas. Em um primeiro momento, e atravessando todos os tempos, ela é a puta, a mulher cujo desejo e gozo estão a serviço do desejo e gozo do homem, uma vez que este detém o poder de comprá-los com dinheiro e/ou de usurpá-los com violência. Em outros momentos, ela é perseguida como a bruxa, aquela que enfeitiça os homens, a pecadora, tomada pelo mal; logo, com o processo de racionalização das crenças e as revoluções científicas, ela se torna "a histérica", cujo mal pode ser domado pela medicina, com eletrochoques e internações em hospitais psiquiátricos. Aqui, trataremos da puta que atravessa todos os tempos.

\section{a. A mulher marginalizada: a puta - regime noturno}

Cabe retomar a trajetória da puta na história, desde que ela foi relegada ao lugar da subalternidade e da marginalidade. A puta é uma figura abjeta da sociedade, lançada aos espaços de condenação moral e de exclusão social; faz parte dos grupos excluídos da sociedade, tal como os 
índios, os moradores de rua e os loucos. Mas há também outra validação contemporânea do imaginário da puta: ela é voz de liberdade; sua atividade é solução para sair de uma situação precária de vida.

Para as profissionais do sexo, a puta pode ser a configuração da liberdade e da independência, encarnadas na transgressão moral. É o que vemos com a história de Leite, autora do livro Filha, mãe, avó e puta (2009). Ser puta é ter a voz daquela que desconsidera todo o discurso opressor, voz de resistência, encarnação e consequente expurgação da liberdade sexual oprimida. A decisão de se tornar prostituta pode representar uma escolha, na medida em que, em termos econômicos, sexuais e emocionais, o exercício da prostituição pode viabilizar, para a mulher, a vivência de uma condição autônoma. No artigo "'Sou feliz sendo prostituta': incidências de discursos governamentais e midiáticos sobre prostituição", Alles e Cogo (2013) mostram o embate entre esse tipo de escolha profissional (apoiado e legitimado por várias instituições, como a Rede Brasileira de Prostitutas e as associações das prostitutas em vários estados) e o discurso dominante no âmbito governamental e mediático, patente quando do episódio ocorrido em 2013 entre o Ministério da Saúde e o movimento das prostitutas:

no Brasil existe somente uma política de tolerância em relação à prostituição - mesmo sendo uma ocupação reconhecida. A repressão moral e das forças policiais é frequente, bem como a intervenção dos agentes e autoridades de saúde, mas não há uma escolha de fato entre a abolição ou a regulamentação da profissão (ALLES e COGO, 2013, p. 18).

O que ocorreu no Brasil, desde os anos da colonização até os dias atuais, foi a manutenção de um imaginário negativo da figura da puta, pois, em decorrência de uma forte herança familiar cristã, nossa cultura colonizada dominante sempre valorizou a virgindade, a monogamia e o patriarcalismo.

Curiosamente, a palavra puta pode ser aproximada do verbo francês puer, "feder", "extrair odor extremamente desagradável". O verbo latino putere significa pourrir, "apodrecer", do qual também origina putois, designação francesa para o animal que exala forte odor, o gambá. Essa 
etimologia somente reforça a ideia de que a imagem que temos da puta está fortemente associada à mulher pecadora e causadora de todos os vícios, exatamente como a prostituta da Babilônia citada no Apocalipse bíblico.

Com isso, podemos entender por que o potencial sexual das pombagiras se consubstancia na figura da puta como deboche da sociedade e sintoma de um sistema social excludente e tirânico. Ambas usam da ironia e do sarcasmo diante da sociedade cristã, sobretudo no Brasil, onde os discursos religiosos e morais legitimam um pensamento opressor, colonizador e patriarcal a respeito das mulheres.

\section{b. A mulher pornográfica: a puta - regime diurno}

No mesmo território da boca do lixo, em que transita a puta, encontra-se a boca do luxo - afinal, é da mesma imagem exaltada, exposta e explorada da sexualidade feminina que a mídia e o comércio pornográfico extraem seu conteúdo e é nela que alicerçam o seu crescimento.

Não é novidade que o mercado publicitário explora sem comedimento a figura da mulher como objeto de desejo e estabelece uma relação explícita entre corpo, sexo e consumo. Esse mercado se beneficia daquilo que Dufour (2013) chamou de "pornocracia", definida a partir de uma lógica de governo que opera sob um sistema ultraliberal e que constantemente emite e propaga o mandamento: "Goze!".

No que concerne à história das imagens, não é de se espantar que o corpo feminino sempre tenha sido alvo de adoração e de grande visibilidade nas culturas, desde as estátuas e pinturas das deusas do amor, representadas com o seu corpo nu, até as mulheres estampadas nas capas de revista. O mercado de entretenimento e a indústria cultural, como sua maior aliada, adotaram o jogo "proibido vs transgressão" como meio sofisticado para gerar exorbitantes lucros. Nasce, assim, um mercado de luxo da prostituição: não distante de nós, sites de acompanhantes ofertam mulheres com as mais diversas qualidades, prostitutas graduadas, que falam mais de um idioma, possuem carros, andam elegantemente 
vestidas e bem apresentáveis socialmente, contrapondo-se, assim, às prostitutas de baixo meretrício.

O jogo entre a proibição e a possibilidade da contravenção é o grande ganho do capitalismo vigente, que lucra sofisticadamente a partir dos métodos de coação cristã longamente construídos. O cristianismo não baniu de todo o pecado, pois precisava dele para exaltar seu aspecto sagrado, como afirma Bataille (2014. p. 162): “O aspecto sagrado do erotismo era o que mais importava à Igreja. Foi para ela a maior razão de punir. Ela queimou as bruxas e deixou as baixas prostitutas viverem". Dessa forma, ela podia afirmar a decadência da prostituição, servindo-se dela para sublinhar o caráter de pecado de uma sexualidade livre das instituições igreja, casamento e família.

Multiplicam-se as putas e prostitutas, movimentando o mercado financeiro e inflando também o desejo do impróprio, a fisgada da traição, a aventura extraconjugal. Há, em cada esposa, um forte desejo de perverter sua condição de pseudossantidade; há, em cada marido, a vontade constante de testar os limites do seu desejo; e há, em cada puta, o idílico sonho de se tornar esposa. É dessa eterna insatisfação, própria do ser humano, que o mercado se nutre, desses desejos mais escondidos dos consumidores.

Vivemos, pois, no meio dessas forças, algo que Dufour chama de "dupla coação" e que nos deixa reféns da publicidade - que exalta a perversão, o vício, a jovialidade e a violência para, dessa confusão, extrair o efeito consumista. A publicidade nos aborda sob o pretexto do "ponto de satisfação", algo que termina por desembocar no consumo:

Ora, estamos na época da cisão: fotos provocantes de Lolitas podem ser encontradas em toda parte. São tantas que já nem são vistas mais. Elas estão constantemente emitindo incitações sadeanas diretas, no sentido em que se dirigem àquele que as contempla aquecendo-o, ou seja, enviando um mandamento que diz: Goze! E, no entanto, o espectador deve frear com toda força para resistir à tentação. Em suma, ele deve meter na cabeça que a foto é apenas para que compre a revista e eventualmente presenteie a namorada com a blusa excitante usada pela mocinha. Nada mais do que isso (DUFOUR, 2013, p. 325). 
Com todas essas incitações, ainda temos dificuldade em aceitar a atividade da prostituta como trabalho. O abjeto, porém, de vez em quando retoma o centro da vida social, da imagem e das telas. É o que pretendemos mostrar nas observações interpretativas a seguir.

\section{Dos estereótipos da cultura falocêntrica às possibilidades da cultura mediática}

Mostraremos aqui como os três artistas pop ${ }^{8}$ escolhidos fazem uso das imagens da putaria e da pornografia, mas também dos estereótipos do desejo e do gozo feminino, para criar um discurso sobre o feminino, a mulher, a androginia e todas as formas que os indivíduos encontram de se identificar com o feminino, numa pluralidade de imagens ora diurnas e apelativas, ora noturnas e enigmáticas.

\section{a. Lady Gaga}

Se seu estilo musical não parece trazer nenhuma novidade, os videoclipes produzidos pela cantora norte-americana Lady Gaga, assim como suas performances de palco, apresentam um discurso e uma estética atípicos e merecedores de nossa atenção. São narrativas que mesclam várias posturas do feminino perante a vida, os sentimentos e os relacionamentos, com a postura de submissão sendo sempre ultrapassada e transformada em posturas de dominação e autocontrole.

Podemos identificar um fio condutor para a interpretação do discurso da cantora Lady Gaga com os seguintes versos de um ponto cantado9 de pombagira: "Juraram me matar com um copo de veneno. Se quiser matar me mata que beber eu bebo mesmo". Versos de um ponto de pombagira que refletem um discurso levado às últimas consequências

\footnotetext{
${ }^{8}$ Vale destacar o modo como os três artistas foram selecionados. Por serem "produtos" do mercado fonográfico e por constituírem objetos da cultura pop, os três carregam no entorno de suas respectivas imagens modeladas um topos do feminino sexual e libertador, mesmo quando reproduzem versos ditos "clichês", frases de efeito e arranjos musicais já excessivamente difundidos - elementos característicos do universo pop.

9 São chamados "pontos cantados" os cantos entoados nos terreiros para evocar determinadas entidades.
} 
do enfrentamento: a morte. Lady Gaga, como as pombagiras, enfrenta com a morte seus sofrimentos para permitir o renascimento de uma nova força, pautada pela liberdade de ser aquilo que se é.

O tema e a estética mórbida são recorrentes em seus clipes e suas performances de palco. Ao mesmo tempo que Lady Gaga pode se apresentar como uma mulher loira, sedutora e padronizada nos moldes da beleza dominante, seguindo uma moda convencional, ela rapidamente assume imagens de estranheza, anormalidade e até monstruosidade e morbidez. A transformação também perpassa todos os clipes. Neles, Lady Gaga assume várias aparências: cabelos longos e lisos alternam com cortes curtos ou desgrenhados, modelos extravagantes associam pretos sensuais e quadriculados burlescos, longos e esvoaçantes vestidos com calças justas e sutiãs metálicos, brancos e coloridos alternam com os pretos e prateados. Joias clássicas com apetrechos sadomasoquistas; várias fantasias futuristas ou animalescas e burlescas. A mutabilidade e versatilidade parecem ser parte da imagem de Lady Gaga, que pode assumir várias faces, papéis e funções dentro de suas próprias narrativas. Mas é constante a dominação que ela exerce sobre os outros. Lady Gaga encarna uma mulher corajosa, sensual, sedutora e dominadora. Às vezes, vingativa. Suas vitimizações, na condição de objeto de desejo de um outro aparentemente mais forte, sempre logram o êxito da superação, da volta por cima ou da vingança.

Outro ponto de pombagira também se adéqua à figura de Lady Gaga: "Ela tem peito de aço e coração de sabiá". A força da mulher que se apresenta em performances, vídeos ou mesmo no documentário The Monster Ball não é alcançada sem a superação das próprias fraquezas. Trata-se de uma mulher que ama, que se emociona e conquista sua liberdade através do exercício de transcendência daquilo que poderia ser fonte de perdição e fracasso: relações amorosas, sentimentos de fraqueza e de impotência diante do amor. Quando se tem "coração de sabiá", é preciso ter "peito de aço", dizem as pombagiras dos terreiros e do imaginário popular brasileiro e Lady Gaga nos palcos mundiais da cultura pop. 
Por fim, no universo mediático e artístico da cultura pop, em que impera a lógica mercantil, com uma forte exploração de imagens pornográficas a serviço do imperativo do gozo, Lady Gaga elabora um discurso de autonomia do próprio corpo. A mulher de suas narrativas não está à venda. Ela tem um alto valor, frequentemente lembrado pela exibição de notas de dólar com seu rosto; porém, não há comprador que possa retificálla. Ela ama seu próprio sucesso, conhece seu próprio valor, mas não se apresenta apenas como objeto para o consumo. Suas danças, seus movimentos, o corpo sinuoso, que ela ora exibe, ora esconde ou insinua, não são mostrados com o fim de seduzir para o consumo da mulher-objeto, mas de mostrar total controle de si, um autocontrole que passa pela aceitação da diferença ("Born this way") e pela venda de um outro produto: a música pop. A respeito do uso da imagem pornográfica, uma grande polêmica foi causada com o lançamento do single "Do What U Want", em função da capa ser a foto da bunda da cantora. Em entrevista à emissora de televisão alemã ProSieben, ela explicou o porquê de ter utilizado uma imagem explícita para a divulgação do single:

[É] apenas mais um pedaço de bunda para você comprar. Você não vai ter o meu coração ou minha mente, porque você não merece. Eu daria aos meus fãs porque eles receberiam com amor. Quando eu vejo como a sociedade mudou, eu sinto que este é um bom momento para mostrar a minha bunda, porque é tudo o que escolhi dar a ela (Lady Gaga apud SANTANA, 2014).

Com isso, a imagem pornográfica ganha outro significado.

É importante lembrar que Lady Gaga inaugurou a fase mais polêmica de sua carreira com o CD Born this way e com a adoção do termo "monstrinhos" para nomear os seus fãs. Uma reação ao imperialismo de um tipo de beleza padronizada e estereotipada. É aos monstros ressurgidos de dentro dos padrões do pop e do massificado que a cantora Lady Gaga se dirige, resgatando-os das profundezas do imaginário noturno: “my little monsters!". 
Assim como Lady Gaga, Valesca afirma e reafirma seu prazer em ser aquilo que é: mulher de corpo sinuoso e volumoso, "gostosa", no vocabulário chulo, ela exibe sua beleza, particularmente as formas que os homens mais desejam - seios, pernas, bunda, ancas -, e os movimentos sensuais que os homens também apreciam - o rebolado, a abertura de pernas -, tudo isso com uma postura de "rainha", ou seja, de mulher poderosa, sentada em trono real, cercada por animais selvagens - o tigre e o falcão ("Beijinho no ombro") -, que lhe conferem poder. Trata-se de uma mulher que também não se deixa subjugar nem por um eventual poder masculino ("Tá pra nascer homem que vai mandar em mim") nem pelo poder da elite social ("Beijinho no ombro" e "Sou a diva que você quer copiar").

Diferente de Lady Gaga, Valesca não nasceu da indústria fonográfica pop internacional, e sim do funk carioca, estilo musical da periferia do Rio de Janeiro tido no Brasil como um dos maiores fenômeno de massa. De fato, Valesca fez sucesso inicialmente com o grupo Gaiola das Popozudas, cujas produções visavam os bailes funk das favelas do Rio de Janeiro, e com suas participações no carnaval carioca. Quando começou sua carreira solo, fez um sucesso massivo com o videoclipe "Beijinho no ombro".

Valesca, no documentário Da favela para o mundo (2014), afirma que não quer deixar de ser funkeira e de representar as favelas cariocas e sua população, sobretudo feminina. Seu clipe "Sou a diva que você quer copiar", em estilo kitsch, encena a dona de casa faxinando com sensualidade. O clipe é patrocinado pela marca Veja, de produtos de limpeza: cores pink e azul bebê, bolhas de sabão, móveis e bibelôs são a marca da cotidianidade da tarefa doméstica. Mas a sensualidade da dança em torno do objeto masculino - um modelo sem camisa, com colar de bottom e quase totalmente estático - diz algo sobre o poder da mulher dominadora, que canta: "Eu já falei que eu sou top, que eu sou poderosa, veja o que vou te falar: eu sou a diva que você quer copiar". O "top" é, ao mesmo tempo, aquele que está no topo na representação dominante de 
beleza ("top model"), mas também o dominador de uma relação sexual (top versus bottom). Valesca canta para as mulheres, dirige-se a elas. Em seu discurso sobre o feminino, o "eu" é incessantemente afirmado, em contraste com as outras, as "inimigas", as "falsificadas", as "recalcadas", as imitadoras. Quem é o "eu” que Valesca afirma e reafirma em todos os seus clipes? O "eu" com o qual as mulheres das favelas e as frequentadoras dos bailes funk se identificam e a partir do qual constroem, por sua vez, sua própria afirmação identitária? Esse "eu” de um feminino que necessita se afirmar por ter sido dominado por muito tempo por uma cultura falocêntrica? O "eu" de mulheres que necessitam concorrer umas com as outras para serem dominantes, tal qual a rainha do conto da Branca de Neve, que não pode tolerar a existência de "alguém mais bela do que ela"? Mas essa mulher que necessita ser "a mais bela” estará realmente concorrendo com as outras? Ou estará apenas participando de um jogo feminino, no qual o sentido de concorrência em busca do poder proporcionado pela beleza é apenas um discurso para o masculino dominante?

A respeito desse jogo feminino, uma aproximação entre o discurso de Valesca e o das pombagiras pode ser feita. Quando estas se autodenominam "rainha do ouro" e chamam as outras de "dona da prata" ou de "fracassadas", elas estão tecendo uma trama de relações e utilizando uma linguagem que pode ter um sentido masculino e outro feminino, ambos seguindo em direções diferentes. De que beleza estão falando? De que poder? Não esqueçamos que as pombagiras riem e gargalham de tudo. Oferecem sentidos a serem interpretados e gargalham, como quem entrega segredos ainda não desvendados. Obedecem a uma lógica não falocêntrica, a uma linguagem feminina do feminino, sobre e para o feminino, necessariamente noturna e enigmática. Estão sempre propondo o diferente com relação ao padrão dominante. Suas palavras e ações mais poderosas são também as mais enigmáticas. Diz o conhecimento popular sobre as pombagiras que, quando riem, é melhor ter cuidado. Porque sua gargalhada obedece ao regime noturno dos ciclos, dos dramas astrobiológicos, da indústria têxtil, e não ao regime diurno 
da tecnologia das armas. As pombagiras tecem tramas intrincadas e resistentes; segredos. Seu discurso velado não pode ser interpretado através de uma lógica diurna masculina. Elas gostam de se oferecer como enigmas. E talvez resida aí o maior indício de um novo discurso feminino sobre o feminino, assumido não só pelas pombagiras dos terreiros de umbanda, mas também pelas suas mais novas representantes da cultura pop.

\section{Azis}

Já o cantor búlgaro Azis subverte a ordem e a normatividade: sua estética pop não fala exclusivamente sobre o feminino, tampouco sobre o masculino. É na fronteira que o artista transita, na região do entre, noção que, para nós, torna-se útil quando necessitamos, também, refletir sobre um feminino que se manifesta através do corpo masculino. A fronteira é o lugar de relação, região de encontro, cruzamento e confronto: "Ela separa e, ao mesmo tempo, põe em contato culturas e grupos. Zona de policiamento é também zona de transgressão e subversão" (LOURO, 2008, p. 19).

Há um certo elemento paródico na performance e nos videoclipes de Azis; por isso o designamos como um personagem fronteiriço. Em sua imitação do feminino sem excluir sua fisionomia masculina, ele se aproxima de uma drag queen, metamorfoseando-se em um ser transgressor e, ao mesmo tempo, estranho e desordeiro. Azis se apresenta como um personagem fora da ordem e da norma, que provoca desconforto, curiosidade e um certo fascínio.

Diferente das representações pop internacionais e das figuras femininas que dominam a indústria fonográfica, o cantor tem pouca visibilidade mundial, embora seja um forte exemplo da atuante indústria cultural do norte europeu. Seu videoclipe disponível no YouTube, Saint Tropez (Азис - Сен тропе), ${ }^{10}$ já atingiu mais de 2,7 milhões de visualizações.

${ }^{10}$ Disponível em: https://www.youtube.com/watch?v=BjSgQFcpLqo. Acesso em: 30 set. 2014. 
Segundo Soares, o pop se caracteriza por reunir um

conjunto de práticas, experiências e produtos norteados pela lógica midiática, que tem como gênese o entretenimento; se ancora, em grande parte, a partir de modos de produção ligados às indústrias da cultura (música, cinema, televisão, editorial, entre outras) e estabelece formas de fruição e consumo que permeiam um certo senso de comunidade, pertencimento ou compartilhamento de afinidades que situam indivíduos dentro de um sentido transnacional e globalizante (SOARES, 2014, [s.p.]).

Sob essa perspectiva, Azis imprime todos os elementos típicos da cultura pop, transportando, no bojo de sua performance, aquele feminino selvagem comum à pombagira. $\mathrm{O}$ cantor pode nunca ter ouvido falar da entidade afro-brasileira, mas atualiza no mainstream formas expressivas bastante comuns à imagem e ao imaginário pombagiresco.

A pombagira "sintetiza os aspectos mais chocantes que a sexualidade feminina pode assumir frente à moral e aos bons costumes" (AUGRAS, 2009, p. 18). Sendo assim, podemos considerar que Azis também assume certos aspectos da pombagira em seu corpo masculino: ser tão lasciva, sensual, sexual e livre em um corpo masculino quanto em um corpo feminino. Vale relembrar que a incorporação das pombagiras não ocorre somente em mulheres, homens também a incorporam.

O que se vê nos vídeos de Azis é luxúria, muita referência a espaços de perversão e putaria, como casas noturnas, saunas e prostíbulos. Suas narrativas transitam entre o universo da prostituição, das drogas e do luxo, conseguindo fazer uma forte crítica ao mercado fonográfico norte americano. Por vezes, as imagens narrativizadas dos videoclipes de Azis parecem nos dizer que se a mulher pode ser erotizada e tornada mercadoria para o desejo de consumo e o imperativo do gozo, podemos fazer o mesmo com a imagem do homem gay. Logo, já não é mais a mulher o objeto da pornografia, mas o feminino. A discussão sobre o lugar do feminino se desloca da mulher para o homem. Já não se trata mais da natureza de uma mulher lasciva, perigosa e subversiva, como vimos com a puta. $\mathrm{O}$ corpo do cantor, extravagante em sua masculinidade tornada feminina, exibe, pois, uma plástica sensual, agindo sob uma 
lógica não estabelecida e não identificada, percorrendo um território pouco habitável, confundindo e tumultuando as categorias até então preestabelecidas. Como uma drag queen, Azis indica que a fronteira entre masculino e feminino é um espaço aberto, que pode ser visitado a qualquer momento.

A drag queen assume a transitoriedade, ela se satisfaz com as justaposições inesperadas e com as misturas. A drag é mais de um. Mais de uma identidade, mais de um gênero, propositalmente ambíguo em sua sexualidade e em seus afetos. Feita deliberadamente de excessos, ela encarna a proliferação e vive à deriva, como um viajante pós-moderno (LOURO, 2008, p. 21).

Azis, porém, não parece estar à deriva. Ele assume, com suas paródias, o papel seguro da crítica a uma cultura pop padronizada e estereotipada. No lugar, coloca-se como um subversivo pop, assumindo a linguagem, as luzes e os clichês da cultura pop para dizer outra coisa.

Podemos afirmar que, por estarem regidas pelo fluxo da feminilidade e por sua anima, as manifestações artísticas da cultura pop são também queer. ${ }^{11}$ Elas falam de um ser estranho, mas um estranho que "questiona, problematiza, contesta todas as formas bem-comportadas de conhecimento e de identidade" (Silva apud LOURO, 2008, p. 48). Ao mesmo tempo, é um território que fala de um feminino que habita toda a natureza e que está presente em todos, qualquer que seja sua configuração - andrógina ou predominantemente mulher ou homem. Quando se manifesta com todas as estratégias visuais do espetáculo pop mediático, o feminino também assume uma fisionomia gay, subverte e contesta os valores estabelecidos, mas, sobretudo, abraça o discurso da alteridade. Basta verificar os fãs masculinos de Lady Gaga e de Valesca Popozuda, em sua maioria, gays. Com Azis, não é diferente. Ele assume formas femininas para falar de e para um universo gay, em resposta a

11 Teoria que emergiu nos Estados Unidos em meados dos anos 1980, a teoria queer refere-se, de forma conjunta, a gays, lésbicas, bissexuais, transexuais, travestis e drags - sujeitos da sexualidade desviante. O queer conota o que é estranho, raro, esquisito, extravagante e extraordinário. 
tudo que nomeia, categoriza, oprime e exclui. A puta gay - abjeção da abjeção - brilha no centro da cena.

\section{Considerações finais}

Em busca da volta do arquétipo da mulher selvagem, encontramos, nas três figuras pop do feminino estudadas, discursos que parecem interpelar o público e que - talvez - justifiquem o sucesso desses cantores, cada um em seu mundo: a norte-americana com seu alcance mundial, proporcionado por uma indústria cultural de potencial internacional; a brasileira partindo das favelas do Rio de Janeiro e sendo projetada nacionalmente, embora também seja fortemente criticada por um discurso local elitista e conservador; o búlgaro chamando atenção do universo gay das regiões norte e sudoeste da Europa, causando, igualmente, fortes polêmicas em seu país.

Os três discursos têm em comum o mesmo recurso retórico: assumir o mal - ou aquilo que pode ser considerado "o mal" por uma visão moral dicotômica - para fazer nascer algo novo de dentro de sua lama; no caso, um feminino novo. Ou talvez, em lugar de novo, devamos qualificar esse feminino de atávico, eterno e primevo, por se tratar de um feminino autêntico em sua dimensão selvagem e instintiva, não mais podado por nenhuma moral, não mais tolhido por nenhuma medida de controle social. Um feminino em vias de libertação, cujos gritos incomodam por serem gritos de subversão de uma ordem imposta por valores ora ultrapassados, mas ainda profundamente arraigados na moral da sociedade falocêntrica.

Contudo, reside na análise dos três casos apresentados a maneira como o arquétipo da mulher livre, sedutora, sexual e selvagem reaparece como formas sobreviventes na performance corporal, nos gestos e nas letras dos cantores. Ao modo da Pathosformel, essa expressão do feminino transgressor é assíncrona, anacrônica e atópica, manifestando-se tanto nos terreiros de umbanda quanto no universo da cultura pop.

A pombagira é, assim como os três cantores pop estudados, contemporânea. Assume as narrativas que, historicamente marcadas, fazem-se 
presentes no sofrimento das mulheres e dos homens que vivem o tolhimento de sua condição feminina reprimida. Partindo desse sofrimento, ela o transcende por meio da dor de ser deliberadamente má: de ser puta, ou puta gay, sexualmente ativa, no controle de suas ações e, sobretudo, de seu desejo. E - pecado dos pecados - de saber usar esse desejo a serviço de si mesma e não mais a serviço do masculino que a quer dominar; saber viver sua própria histeria, sua própria sensualidade, sua própria sexualidade e ser, finalmente, um ser criativo e livre.

\section{Referências}

ALLES, N.; COGO, D. Sou feliz sendo prostituta: incidências de discursos governamentais e midiáticos sobre prostituição. Esferas: revista Interprogramas de Pós-Graduação em Comunicação do Centro-Oeste, ano 2, n. 3, p. 11-20, julho/dezembro de 2013.

AUGRAS, M. Imaginário da Magia: magia do imaginário. São Paulo: Vozes, 2009.

BAITELLO JR., N. A era da iconofagia. São Paulo: Hacker, 2005.

BATAILLE, G. O erotismo. São Paulo: Autêntica, 2014.

CHARBEL, Felipe. Aby Warburg e a pós-vida das pathosformeln antiga. História da historiografia. Ouro Preto, v 5, p 134-147, setembro de 2010.

DA FAVELA para o mundo. Direção: Marcos Júnior. Produção: Pardal Produções.

Documentário, 15,52". Disponível em: <https://www.youtube.com/ watch?v=A4xIU9D4Z4U>. Acesso em novembro de 2015.

DIDI-HUBERMAN, G. A imagem sobrevivente. História da arte e tempo dos fantasmas segundo Aby Warburg. Trad. V. Ribeiro. Rio de Janeiro: Contraponto, 2013.

DRAVET, F. "A formação das imagens do feminino na cosmologia da umbanda e sua manifestação no imaginário brasileiro", Anais do XXII Encontro Anual da Compós, Salvador, 2013. Disponível em http://encontro2013.compos.org.br/anais/imagem-e-imaginarios-midiaticos/. Acessado em 15/11/2015.

DUFOUR, D-R. A cidade perversa. Rio de Janeiro: Civilização Brasileira, 2013.

DURAND, G. As estruturas antropológicas do imaginário. São Paulo: Martins Fontes, 2012.

JUNG, C. G. Os arquétipos e o inconsciente coletivo. Rio de Janeiro: Vozes, 2011.

LEITE, G. Filha, mãe, avó e puta: a história de uma mulher que decidiu ser prostituta. Rio de Janeiro: Objetiva, 2009.

LOURO, G. L. Um corpo estranho: ensaios sobre sexualidade e teoria queer. Belo Horizonte: Autêntica, 2008. 
MORIN, E. Cultura de massas no século XX. v. 1. Neurose. Rio de Janeiro: Forense, 2007.

OXALÁ, A. Igbadu: a cabaça da existência. São Paulo: Palas Athena, 1998.

SANTANA, J. de S. Do monstro da fama ao nascimento da vênus: um livro-arte sobre Lady Gaga. 2014. Trabalho de Conclusão de Curso. (Comunicação Social / Publicidade e Propaganda) - Universidade Católica de Brasília. 56p.

SANTOS, J. E. Os nagô e a morte. São Paulo: Vozes, 2001.

SOARES, T. Abordagens teóricas para estudos sobre a cultura pop. Logos. Comunicação e Universidade. Rio de Janeiro: Uerj, v. 2, n. 24, 2014.

WARBURG, A. L'Atlas Mnémosyne. Paris: L'écarquillé, 2012.

Data de submissão: 04/08/2015

Data de aceite: 28/11/2015 